\title{
OPENING ADDRESS
}

\section{Perspectives in coronary prevention}

\author{
R. W. D. TURNER \\ O.B.E., M.A., M.D., F.R.C.P., F.R.C.P.E.
}

\section{Summary}

The seeds of premature coronary heart disease are often sown in childhood and it is the developing arteries of children which are the most susceptible. Paediatricians and all who work with them have the earliest and most promising opportunities for prevention.

Coronary protection can be added to the potential advantages of breast feeding and to ensure appropriate fatty acid balance throughout weaning.

It is reasonable to accept the strong consensus of opinion on diet reflected in the reports of the eighteen national committees. They are: to reduce total fat intake to $30-35 \%$ of the energy, to restrict consumption of saturated fat, cholesterol, sugar, and salt, to increase unrefined carbohydrate and polyunsaturated fat, and to maintain a P/S balance of 1.0-1.5 : 1 .

Food is the fundamental coronary risk factor, but others may add insult to injury. Smoking, hypertension, obesity, lack of exercise, and stress, each of which is related to behaviour, may start in childhood. Smoking doubles the overall risk of CHD and increases it ten times in males under $\mathbf{4 5}$ years old. Good habits, including food preferences and eating patterns learned early, are those most likely to be continued.

School meals require and should match revised nutritional education.

The co-operation of the food industry is essential and can be anticipated, but it requires a clear lead by paediatricians.

The nutritional advice should come from the medical profession.

Every contact with children and their parents provides an opportunity for enquiry and giving advice.

MY brief is to try to put the problem of coronary prevention in perspective with particular emphasis on the paediatric aspects.

Owing to the high incidence of sudden death and the usual severity of underlying arterial disease when symptoms first appear, little more can be done to reduce overall mortality by acute coronary care. And since the arterial disease frequently starts in infancy or childhood, and tends to be progressive, only primary prevention is likely to be effective. Paediatricians and all who care for children have a great opportunity and, perhaps it may reasonably be suggested, commensurate responsibility.

Coronary heart disease (CHD) is the commonest cause of death in the U.K. after the age of 35 years and accounts for more than $33 \%$ of all deaths before the age of 65 years.

New data from the world's longest prospective study, taking place at Framingham in the United States, are said to be representative of those in other centres. There is little reason to doubt that the situation is much the same in the U.K. because we have a similar overall mortality, and Scotland now has the highest of all.

Put in paediatric perspective, one male child in three is likely to have a heart attack, a stroke or one of the less common manifestations of atherosclerosis in his 40 s or $50 \mathrm{~s}$, and sometimes earlier (Kannel, 1976). This means a corresponding number of widows and considerably more fatherless children.

That the main causes must largely be environmental in origin and due to behavioural change is indicated by:

(1) The recent steep rise in incidence in many Western countries (Fig. 1).

(2) The wide population variations between countries which cannot be explained by race.

(3) The experience of migrants from low- to highrisk countries where they soon start to develop CHD.

(4) The changes in mortality which occurred during and after the war in many occupied European countries.

There are in fact only four types of behavioural change to be considered: the food and drink we consume; the air we breathe (smoking); the exercise we fail to take; the stress to which we are exposed, or expose ourselves.

Smoking is only an important risk factor for CHD in countries habitually consuming a modern Western-type 'atherogenic' diet. Stress and physical inactivity probably fall into the same category. Hypertension and diabetes certainly do.

The evidence indicates that only food is fundamental to this modern epidemic, yet this appears to be the aspect about which there is the most 
TABLE 1. Recommendations of 18 committees on food and coronary heart disease

\begin{tabular}{|c|c|c|c|c|c|c|c|}
\hline Country & $\begin{array}{c}\text { General } \\
\text { population } \\
(\mathrm{GP}) \\
\text { high risk } \\
\text { group (HR) }\end{array}$ & $\begin{array}{c}\text { Fat content } \\
\text { of total } \\
\text { energy }(\%)\end{array}$ & $\begin{array}{l}\text { Increased } \\
\text { PUFA }\end{array}$ & $\begin{array}{l}\text { PUFA-SAFA } \\
\text { ratio }\end{array}$ & $\begin{array}{l}\text { Daily } \\
\text { dietary } \\
\text { cholesterol } \\
\text { (mg) }\end{array}$ & $\begin{array}{l}\text { Reduction } \\
\text { of sugar }\end{array}$ & $\begin{array}{l}\text { Labelling } \\
\text { of fat } \\
\text { content } \\
\text { of foods }\end{array}$ \\
\hline $\begin{array}{l}\text { Norway, Sweden and } \\
\text { Finland, } 1968\end{array}$ & GP & $25-35$ & Yes & - & - & Yes & Yes \\
\hline $\begin{array}{l}\text { New Zealand, } 1971 \\
\text { Heart Foundation }\end{array}$ & $\begin{array}{l}\text { GP } \\
\text { HR }\end{array}$ & $\begin{array}{l}35 \\
35\end{array}$ & $\overline{\text { Yes }}$ & $\overline{1 \cdot 0}$ & $\begin{array}{l}300-600 \\
300-600\end{array}$ & No & Yes \\
\hline $\begin{array}{l}\text { New Zealand, } 1971 \\
\text { Royal Society }\end{array}$ & $\begin{array}{l}\text { GP } \\
\text { HR }\end{array}$ & $\begin{array}{l}\text { Avoid excess } \\
\text { saturated fat }\end{array}$ & $\begin{array}{l}\text { No } \\
\text { Yes }\end{array}$ & - & $\begin{array}{l}\text { Reduce } \\
\text { Reduce }\end{array}$ & 二 & - \\
\hline $\begin{array}{l}\text { International Society } \\
\text { of Cardiology, } 1973\end{array}$ & HR & $<30$ & Yes & $>1 \cdot 0$ & $<300$ & 一 & Yes \\
\hline $\begin{array}{l}\text { United States, } 1973 \\
\text { American Heart Association }\end{array}$ & GP & 35 & Yes & $1 \cdot 0$ & 300 & Yes & Yes \\
\hline The Netherlands, 1973 & GP & 35 & Yes & $1 \cdot 0$ & $250-300$ & Yes & Yes \\
\hline $\begin{array}{l}\text { United States, } 1973 \\
\text { White House Conference }\end{array}$ & GP & 35 & Yes & - & 300 & - & Yes $\frac{c}{c}$ \\
\hline $\begin{array}{l}\text { Australia, } 1974 \\
\text { National Heart Foundation }\end{array}$ & $\begin{array}{l}\text { GP } \\
\text { HR }\end{array}$ & $30-35$ & Yes & $1 \cdot 5$ & $<300$ & $\overline{\text { Yes }}$ & $-\stackrel{\bar{a}}{\equiv}$ \\
\hline $\begin{array}{l}\text { United Kingdom, } 1976 \\
\text { Royal College of Physicians } \\
\text { and British Cardiac Society }\end{array}$ & GP & Towards 35 & Yes & 0 & Reduce & Yes & Yes \\
\hline $\begin{array}{l}\text { Norway, } 1976 \\
\text { Ministry of Agriculture }\end{array}$ & $\begin{array}{l}\text { GP } \\
\text { HR }\end{array}$ & $\begin{array}{l}35 \\
35\end{array}$ & $\begin{array}{l}\text { Yes } \\
\text { Yes }\end{array}$ & $\begin{array}{l}0 \cdot 5 \\
1 \cdot 0\end{array}$ & $\begin{array}{l}\text { Doctor's } \\
\text { decision }\end{array}$ & Yes & Yes \\
\hline $\begin{array}{l}\text { Canada, } 1976 \\
\text { Health \& Welfare }\end{array}$ & $\begin{array}{l}\text { GP } \\
\text { HR }\end{array}$ & $\begin{array}{l}30-35 \\
30-35\end{array}$ & $\begin{array}{l}\text { Yes } \\
\text { Yes }\end{array}$ & - & $\begin{array}{l}400 \\
400\end{array}$ & $\begin{array}{l}\text { Yes } \\
\text { Yes }\end{array}$ & Yes \\
\hline $\begin{array}{l}\text { United States, } 1977 \\
\text { Senate Committee }\end{array}$ & $\begin{array}{l}\text { GP } \\
\text { HR }\end{array}$ & $\begin{array}{l}30 \\
30\end{array}$ & $\begin{array}{l}\text { Yes } \\
\text { Yes }\end{array}$ & $\begin{array}{l}1 \cdot 0 \\
1 \cdot 0\end{array}$ & $\begin{array}{l}300 \\
300\end{array}$ & $\begin{array}{l}\text { Yes } \\
\text { Yes }\end{array}$ & 一 \\
\hline
\end{tabular}

uncertainty in the minds of the medical profession. However, eighteen consecutive committees from many different countries have reached a remarkably strong consensus of opinion (Table 1), as will be discussed.

This is not at all to decry the importance of the other factors in high risk communities such as ours.

Table 2 serves to illustrate some important points.

Finland has long had the highest mortality from
CHD in the world, the highest plasma cholesterol $/$ levels, the highest consumption of saturated fat and $N$ the lowest polyunsaturated/saturated $(\mathbf{P} / \mathbf{S})$ fat ratio in their diet.

Japan on the other hand has the lowest mortality of all countries considered to have good statistics. They are a well fed, modern industrialized, stressful, heavily-smoking and unusually hypertensive popula-: tion, but have little coronary or other atheromatous $\frac{T}{0}$ disease. The explanation, taken in conjunction with $\stackrel{\mathrm{D}}{\mathrm{O}}$ 


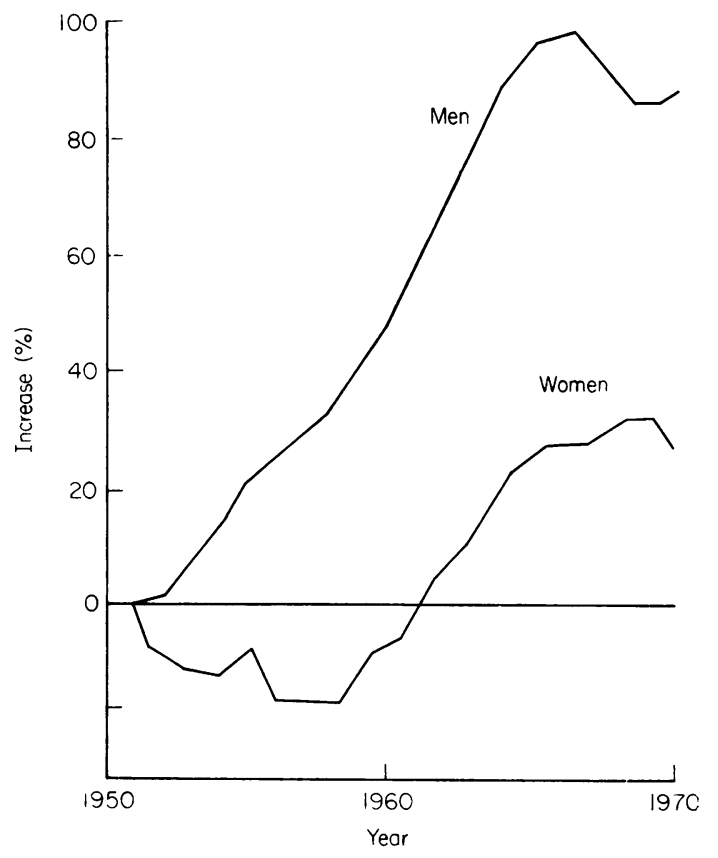

Fig. 1. Percentage increase in death rates due to coronary heart disease of men and women in England and Wales in age group 35-44 years.

information from other countries, clearly lies in their habitual diet and correspondingly low plasmacholesterol levels. However, if the Japanese migrate, as they have done in large numbers to the United States, and change their eating habits, blood cholesterol levels start to rise, atherosclerosis develops and in due course they develop as much CHD and cerebral infarction as do the Americans amongst whom they live.

There is no proof of the dietary hypothesis in the strict sense of conclusive evidence based on controlled dietary trials, but it has been reluctantly decided that such studies are impossible to carry out (National Heart and Lung Institutes, 1971). However, the links between diet, hypercholesterolaemia, atherosclerosis and CHD are immensely strong. The evidence includes clinical and pathological observations (including the International Atherosclerosis Project, 1968), population surveys, migrant studies, prospective epidemiological studies, laboratory investigations on mechanisms and a favourable trend in most preventive trials already carried out.

It is supported by a vast amount of experimental work in many species. Wissler and Vesselinovitch (1968), by using human diets in non-human primates very similar to man as regards coronary arterial anatomy and plasma lipoproteins, have produced atherosclerosis closely similar if not identical to that
TABle 2. Mortality due to coronary heart disease (males 45-54 years, deaths per 100000 - WHO 1971)

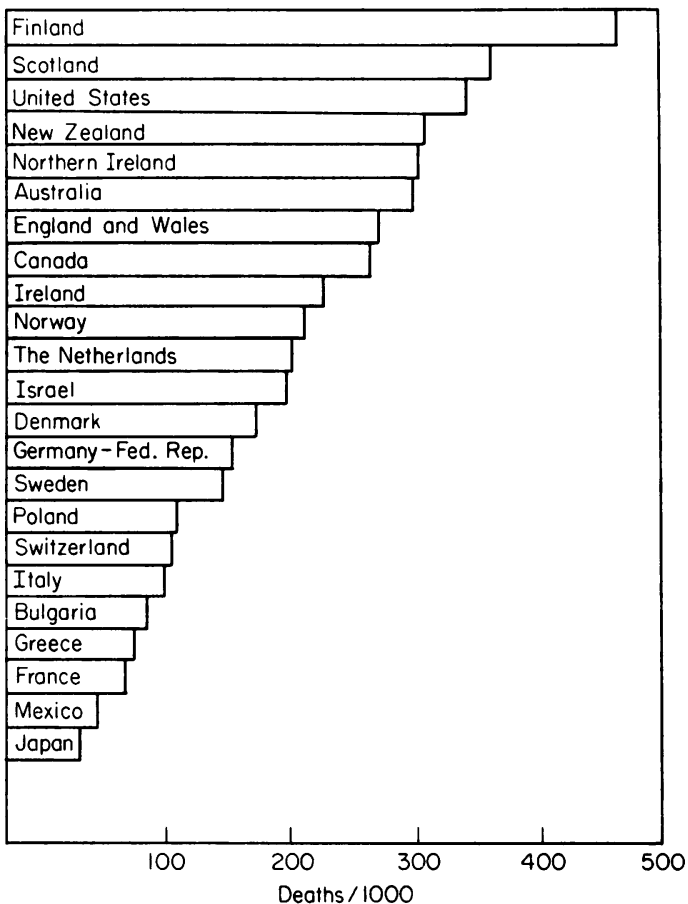

which occurs in man, and with similar complications. Impressively the changes are mild and do not occur if instead a 'prudent' diet, similar to that now being widely recommended, is given. Encouragingly, if the lesions are not too advanced, considerable regression may follow on changing back to their normal diet (Armstrong, Warner and Connor, 1970; Wissler, 1977).

\section{What has man done?}

Evolving man was breast-fed for the first 12 months or longer with milk perfected as an allsufficient food. He was not obese, did not smoke and was active from dawn till dusk. His meat was lean, his carbohydrate unrefined and sugar and salt were not added to his food. There was no dairy produce or processing of food.

Progressively since World War I there has been a decline in breast feeding, and replacement by bottle feeding with a substitute of entirely different composition, suited for rapid growth of muscle and bone but not for a highly complex nervous system with corresponding vascular supply. Cow's milk has a much higher protein content and is often antigenic. In particular, the concentration of polyunsaturated fatty acids which are essential for the 
growth, development and later the maintenance and repair of all cell membranes, including those of the arterial wall, is extremely low.

Solids are given early and often of unsuitable type. Over-nutrition is common and sugar and salt are added to maternal taste. Weaning is carried out on to a modern atherogenic diet, high in saturated fat, cholesterol and sugar, with a very low polyunsaturated/saturated $(\mathbf{P} / \mathbf{S})$ ratio, the significance of which is important. Some proprietary baby foods are not exempt, particularly as regards fatty acid composition, sugar and salt. School meals are unsatisfactory, with out-dated emphasis on meat and use of saturated fats and oils because they are the cheapest.

Cereals are usually refined, thereby removing important nutrients and the fibre. Dairy fat is consumed in excess, particularly by children and young adults, and later animal and other saturated fat in meat products and 'convenience' foods of many kinds, including cakes, biscuits, puddings, frozen desserts, confectionery, most margarines and shortenings.

In the home the trend is towards less basic foods and home-prepared meals and more convenience and luxury items.

There is much evidence to suggest that the answer to the coronary problem lies basically in correction of many of these unfavourable aspects of our diet. Atherosclerosis often starts in childhood and preatherosclerotic changes are frequently present in infancy.

\section{Paediatric attitudes}

Some paediatricians have been reluctant to accept that modifications in the national diet now widely agreed for adults are applicable to children and are particularly important (American Academy of Pediatrics, Committee on Nutrition, 1972; American Heart Association Committee, 1973; Schubert, 1973). This may in part be due to lack of appreciation of the radical changes they have unwittingly condoned and which came about unplanned and untested. Some have advised long-term controlled dietary trials on the Framingham pattern but starting in infancy (Drash and Hengstenberg, 1972) before making any changes but such trials would be impossible if only through having to be continued for $40-50$ years.

A policy of prevention for the whole family by correcting the changes, which have been made and which are so likely to be largely responsible for the arterial changes in childhood, seems fully justified. The answer can only come by making this 'experiment'. It could hardly involve risk commensurate with that of not taking action.

\section{'No action without proof'}

Those who maintain the philosophy that dietary advice should not be given without conclusive evidence that benefit will result should ponder on what they are waiting for and for how long they areo prepared to wait.

We have a serious situation, with no likelihood of $\frac{\overline{\bar{s}}}{}$ 'proof' in the foreseeable future, if ever, or of signi- $\widehat{\Phi}$ ficantly better detection of many at high risk, and there will be no spontaneous improvement. In this context, Rose (1975) advocates 'energetic action? without proof of its efficacy' which he considers to $\overrightarrow{\vec{\omega}}$ be an unreasonable condition.

\section{Heredity}

Coronary heart disease tends to run in families, $\rightarrow$ but it is often difficult to distinguish the roles of heredity and similar habits. As Kannel and Dawber (1972) put it, 'Families share more than genes'. How- $\overrightarrow{\vec{A}}$ ever, the role of heredity as a risk factor has been $\overrightarrow{ }$ exaggerated in the sense that it is only of significance 5 in those who habitually consume an unsuitable diet. Predisposition does not apparently matter in lowrisk countries unless individuals migrate and change $\frac{\widetilde{O}}{\mathcal{O}}$ their dietary habits. The answer to the coronary problem mainly lies in the way we live.

These comments do not of course apply to genetic hyperlipidaemias.

\section{Pre-atheroma}

It has long been known that atherosclerotic $\stackrel{2}{\circ}$ plaques, sometimes causing severe narrowing or $\cong$ even occlusion of the lumen, are by no means rare $\overrightarrow{\overrightarrow{0}}$ in young adults. Lesser changes must be present at 3 an earlier age than this and be preceded by microscopical evidence.

Osborn $(1963,1967)$ studied the coronary arteries $\overline{0}$ of 1500 infants, children and adolescents. $\mathrm{He} 3$. demonstrated histologically that the coronary arteries were abnormal more often than not by the age of 15 years, frequently by the age of 5 years and not $O$ uncommonly in infancy. Under the age of 5 years $₹$ the lesions did not contain lipid. Similar changes 윽 have been described by other pathologists and are $>$ considered to be pre-atheromatous (Lober, 1953; 을. Schornagel, 1956; Moon, 1957; Daoud et al., 1964; Nু Pesonen, 1974).

Osborn noted that the lesions were more common $N$ and severe in the dominantly bottle-fed than in the $\underset{\omega}{N}$ dominantly breast-fed. Many of the children had been killed accidentally, with no history of anyo other preceding event.

Pesonen (1974) found that changes might be $\stackrel{\oplus}{+}$ present on the first day of life, which at least brings 0 up the possibility that maternal feeding during pregnancy may have been related. 
It used to be thought that fatty streaks were the usual precursors of atherosclerosis (International Atherosclerosis Project, 1968; McMillan, 1973), but this now seems unlikely, at least in childhood. They have been found in all populations, whether there is a high or low incidence of atherosclerosis in adult life, they have a different anatomical disposition from atherosclerotic plaques (Mitchell and Schwartz, 1965) and a different fatty acid composition (Sinclair, 1968), suggesting local synthesis rather than infiltration from the plasma.

A possible cause which has been suggested is an antibody reaction to cow's milk protein (Davies et al., 1974). My view is that, at this age, in the absence of some event (such as infection, hypoxia, hypotension, stress, dehydration or collapse from any cause such as gastro-enteritis), essential fatty acid (EFA) deficiency is the most likely cause. Cow's milk is very low in EFAs compared with breast milk, and they are necessary for the development and integrity of all cell membranes, including those of vascular tissue. However, no matter what the cause(s), it can be anticipated that injury would normally be followed by repair but, given an unsuitable nutritional environment, such as that now habitually present in most children, the changes are very likely to be a basis for atheroma.

\section{The consensus of opinion}

In recent years eighteen national committees have reviewed the evidence on diet in relation to CHD and made recommendations which are remarkably similar. The countries include the U.S.A., Canada, Australia, New Zealand, Norway, Sweden, Finland, The Netherlands, West Germany and the U.K. (Table 1).

Each $(18 / 18)$ has recommended a reduction in the consumption of saturated fat either by the population as a whole (14) or for those found on screening to be at high risk (4). Since, at present, screening of whole populations is not feasible and many individuals who are not at high risk by conventional standards develop CHD, advice must be for all who wish to take reasonable precautions.

A partial substitution of saturated by polyunsaturated fat was specifically recommended by $16 / 18$, and also that there should be restriction of dietary cholesterol.

Most considered that carbohydrate should be mainly unrefined, and consumption of sugar reduced. Many also advised salt restriction. The principles apply to children.

In view of this strong consensus of informed opinion, emphasized by Truswell (1976), the excuse for inaction which is sometimes made that 'doctors are divided' seems hardly justified.

\section{Saturated fat}

Present-day excessive consumption of saturated fat comes mainly from (a) dairy produce; (b) meat and meat products (including animal cooking fat); (c) imported coconut and palm oil and hydrogenated vegetable and marine oils, widely used by the food industry.

\section{Dairy fat}

'Use butter sparingly, and in general avoid cream and top of milk' is implicit in the reports of each of the 18 committees which have recommended restriction in the consumption of saturated fat. In the U.K., with $20 \%$ of the EEC population, we consume more than $40 \%$ of the milk, and it is the richest in cream. Consumption of butter is high. In 1973, $42 \%$ of our food energy came from fat and about half of this was saturated. Nearly $50 \%$ came from dairy produce, and about half of this was from butter and cream. Dairy fat makes the largest contribution to saturated fat in the diet of children and young adults. Morris (1973) has emphasized that one of the malnutritions of affluence is the rising consumption of dairy fat. In Finland (Keys, 1970; Keys and Keys, 1975) and Belgium (Joossens et al., 1977) high mortality from CHD has been closely correlated with butter fat.

Milk is customary, convenient, nutritious and good value for money, but the goodness is in the skim. Energy and vitamins are better obtained from other sources. It would be sensible if the fat content of full-cream milk was reduced, as on the Continent, and half-cream and skimmed milk were readily obtainable. Milk for babies should be 'humanized' and older children should not be given full-cream milk. In Sweden they have had only skimmed milk for many years.

Butter has no known nutritional value over margarine, and it is better for children not to acquire the taste for it. Suitable soft margarines have the advantages of being lower in saturated fat, higher in polyunsaturated fat and free from cholesterol,

It would be to our nutritional advantage if the Milk Marketing Board and Butter Information Council were discouraged from their excessive promotional activities.

\section{Polyunsaturated fat and the $P / S$ ratio}

Almost all (16/18) working parties have advised partial substitution of saturated (S) by polyunsaturated (P) fat. The changes which have come about in our diet have resulted in a 5- to 10-fold reduction in the $P / S$ ratio. Owing to competition between enzyme systems, this imbalance affects the fatty acid composition of phospholipids in cell membranes and of triglyceride and cholesterol esters. Polyunsaturated fatty acids (PUFAs) are essential for 
the development of all cell membranes, including those of the arterial wall of which they form a high proportion, and for their functional and structural integrity as well as physical properties, such as plasticity. This is particularly important in the growing child because it is developing tissues which are most susceptible to injury. In view of the preatheromatous changes frequently found in infants and young children, it seems unwise to run any risk of compromising this situation. PUFAs constitute $6-8 \%$ of the energy in breast milk, and this should surely be accepted as the physiological standard for any substitute. Cow's milk is very low in PUFAs and National Dried Milk was not humanized in this respect.

After the child has been weaned, the proportion of PUFAs needs to be raised in order to balance the increasing consumption of saturated fat. The $\mathrm{P} / \mathrm{S}$ should be $>1 \cdot 0$, and it is probably best that total fat should not exceed $30 \%$ of the energy. Appreciation of the mechanisms involved gives confidence in supporting these recommendations.

PUFAs also reduce plasma cholesterol levels and counter the effect of saturated fat and of dietary fat in raising them (Keys, Anderson and Grande, 1965; Nestel, Carrol and Havenstein, 1970). Much evidence indicates that the lower plasma cholesterol levels are maintained, the better. Likewise PUFAs reduce plasma triglyceride levels and counter the synergism between saturated fat and carbohydrate in raising them (Macdonald, 1973).

PUFAs control platelet adhesiveness and aggregation and hence influence thrombus formation, probably through their prostaglandin derivatives (Hornstra, 1974). In man, dietary manipulation to restore a natural $\mathrm{P} / \mathrm{S}$ balance of about $1.5: 1$ was associated with a reduction in the incidence of thrombotic complications of atherosclerosis (Miettinen et al., 1972; Hornstra et al., 1973).

Prostaglandins have other important regulatory functions including that of vascular tone. Recently it has been shown that increasing consumption of polyunsaturated fat reduces elevated blood pressure levels (Lee, 1976; Vergroesen, 1977).

The composition of the fatty acids released trom triglycerides stored in adipose tissue, in response to catecholamine secretion, is likely to be an important aspect of smoking and stress as coronary risk factors.

Experimentally it has been shown that PUFAs protect against atherogenesis and thrombogenesis.

There are therefore good reasons for maintaining a balanced diet as regards total fat and its fattyacid composition. Excessive restriction of fat is unlikely to be acceptable, and is unnecessary. Fortunately it can be done without undue difficulty.

There is no evidence that polyunsaturated fat, in the amounts recommended, has any harmful effecto (Nestel, 1974). In diets containing $30-35 \%$ of the energy as fat, a $\mathrm{P} / \mathrm{S}$ ratio of 1.5 will provide no more. PUFA than that habitually consumed by mane Europeans and others. Evidence for the suggestiog that PUFA might cause cancer was examined by Heady (1974) who concluded that the case was nof merely unconvincing, but did not stand examination

Correction can be made by reducing consumption of saturated fat from meat and meat products? dairy produce and convenience foods, and increasing polyunsaturated fat by eating more fish and poultr $\overrightarrow{\mathrm{x}}$ (in place of meat), more cereals, vegetables, frui and nuts and using a polyunsaturated soft margaring and cooking oil.

\section{Dietary cholesterol}

Dietary cholesterol is surplus to requirement because the body synthetises sufficient for all its needs. Consumption has been increasing. All animat tissues contain cholesterol, but the richest source is egg yolk. Dietary cholesterol contributes on average. $0.25-0.33$ of plasma cholesterol, but sometimes morez It is provedly and powerfully atherogenic in nono human primates, and there is no justification fo? assuming the situation may be different in man Restriction of consumption to about $300 \mathrm{mg} / \mathrm{d}_{\mathrm{a}}$ has been advised for adults by almost all committefes and Fomon (1974) advises moderate restriction yond infancy. In children this means not more that 1-2 egg yolks/week, depending on age. Raised plasm\$ cholesterol levels in school children and young adulto are being increasingly reported in affluent countries? This is likely to be the forerunner of CHD.

\section{Hypertension and diet}

Different blood pressure levels, even within the normal range, are often established in childhoods Thereafter the same 'ranking' order tends to be maintained (Hatch, 1974). Mortality and morbidit? from untreated hypertension are greatest when it has. been diagnosed in the young.

Essential hypertension is based on the combination of polygenic inheritance and multiple environmentas influences. It has been increasingly reported its children. Obesity is often associated with hyper. tension and hyperlipidaemia which, as Kannel and Dawber (1972) says, is a particularly ominous com? bination, and both fall with its reduction. Obesit therefore should be avoided or corrected.

There is much clinical, epidemiological and experie mental work to suggest that salt plays an important role in pathogenesis (Freis, 1976) although it iष్ impossible to carry out dietary studies to prove this? Sensitivity to dietary salt varies widely, but thiso could be an important factor in the $10-15 \%$ of the middle-aged population who are hypertensive. Sal 18 
is an acquired taste, and should not be added to infants' feeds or children's meals. Obviously salty products, such as certain concentrated yeast extracts, should be avoided.

The main risk of mild-moderate hypertension is that of accelerated atherosclerosis. Severe hypertension with the risk of cerebral haemorrhage and cardiac failure is relatively uncommon. It is therefore important to give explicit advice on diet, smoking and other risk factors in relation to both cerebral and myocardial infarction.

Morris (1973) quoting a WHO seminar emphasized that 'there is no single medical measure which would make such a contribution to the quality of life in old age as the prevention of stroke'. Prevention logically starts with appropriate nutrition in childhood.

\section{Obesity}

Obesity is easier to prevent than reduce, and more frequent in the bottle-fed than the breast-fed infant, In the well child, the main purpose of weighing is to detect overnutrition. Obesity itself, unless gross, is not a major coronary risk factor, but tends to be associated with hypertension and hyperlipidaemia.

In giving dietetic advice on calorie restriction, it is important to explain details of the 'fat-switch' from saturated to polyunsaturated fat.

\section{Exercise and coronary prevention}

Children now rarely walk or cycle to school, and later most abandon games. Watching television has become the favourite recreation. Many studies suggest that physical inactivity is an important coronary risk factor and that regular exercise may play a part in protection. Although this cannot be proved, exercise certainly improves the quality of life and has a number of favourable effects.

Regular exercise helps to control body weight and plasma lipid levels. Fibrinolysis is increased and platelet aggregation decreased. Cardiopulmonary function is improved and vascular resistance reduced. Autonomic control is changed towards relative vagotonia with a lower pulse rate and blood pressure and lesser catecholamine secretion in response to stress.

The importance of maintaining regular exercise should be part of health education and illustrated by explanation of its physiological effects. It is ideal when families take exercise together.

\section{School meals}

The recommended composition of school meals has not yet been changed to accord with the consensus of opinion, including that of the DHSS (COMA) Panel (1974). The principal fats used in cooking are highly saturated, because they are the cheapest. There is still an excessive emphasis on meat which contains much saturated fat, owing to the agricultural practice of 'finishing' for the market. Most meat products are even fatter. Meat is a good source of nutrients, but so are fish and poultry which have the advantages of being low in fat, but relatively high in essential fatty acids. As stated by Davidson et al. (1975), 'Protein of animal origin is not essential for man, as has been amply demonstrated by many vegetarians'.

Although some meat meals should be included in school menus, children should be taught that meat is unnecessary for perfect health and expensive to produce, and that feeding cereals to animals is wasteful in view of the world shortage. A combination of cereals and legumes (peas, beans, lentils) provides all the essential amino acids and other important nutrients, but not unwanted saturated fat and cholesterol. Meat is not necessary as a source of iron as sometimes suggested. Vegetarians are not anaemic. Cereals should be unrefined to preserve the germ and the fibre.

\section{Nutritional advice from commercial firms}

It is anomalous that advice on infant, childhood and maternal feeding should come mainly from firms with vested interests. The industry has achieved too dominant a place, perhaps because the medical profession has shown so little interest in nutrition and been acquiescent. There is risk of conflict between profit-making and nutritional considerations. Commercial concern should be in the realm of food technology, and policies should be laid down by the medical profession (Editorial, 1976).

The National Dairy Council issues booklets advising greater consumption of foods which virtually all experts consider should be restricted, and make no mention of which should be encouraged.

However, there is no reason to doubt that the industry as a whole would co-operate if given a clear lead.

\section{Research}

An important research study would be to bring up children on a propertly balanced diet and observe the results.

A health record card, made out at birth, could include details of the family history, infant feeding and subsequent illnesses. A copy could be centrally stored for easy retrieval in order to make comparisons with pathological changes in the arterial wall, in children killed accidentally or dying from unrelated disease.

I can think of no other way in which the relationship of nutrition to developing arterial disease could be found.

A study of the effect of diet, smoking, stress and 
exercise on high density lipoprotein (HDL) also needs to be carried out, since HDL is known to be of predictive value.

\section{References}

American Academy of Pediatrics, Committee on NutriTION (1972) Childhood diet and coronary disease. Pediatrics, 49, 305.

American Heart Association Committee (1973) Estimating the risk of coronary heart disease in daily practice. Coronary Risk Handbook. American Heart Association, New York.

Armstrong, M.L., Warner, E.D. \& Connor, W.E. (1970) Regression of coronary atheromatosis in rhesus monkeys. Circulation Research, 27, 59.

DaOud, A., Jarmolych, J., Zumbo, A., Fani, K. \& FlorenTIN, R. (1964) 'Preatheroma' phase of coronary atherosclerosis in man. Experimental and Molecular Pathology, 3, 476.

Davidson, S., Passmore, R., Brook, J.F. \& Truswell, A.S. (1975) Human Nutrition and Dietetics, 6th edn. Churchill Livingstone, Edinburgh.

Davies, D.F., Johnson, A.P., Rees, W.B.G., Elwood, P.C. \& ABERNETHY, M. (1974) Food antibodies and myocardial infarction. Lancet, i, 1012.

Department of Health \& Social Security (COMA) 1974 Diet and coronary heart disease. H.M. Stationery Office, London.

Drash, A. \& Hengstenberg, F. (1972) The identification of risk factors in normal children in the development of arteriosclerosis. Annals of Clinical Laboratory Science, 2, 348.

EDITORIAL (1976) The infant-food industry. Lancet, ii, 503.

Fomon, S.J. (1974) Infant Nutrition, 2nd edn. W. B. Saunders Co., Philadelphia.

FreIS, E.D. (1976) Salt volume and the prevention of hypertension. Circulation, 53, 598.

HATCH, F.T. (1974) Interactions between nutrition and heredity in coronary heart disease. American Journal of Clinical Nutrition, 27, 80.

Heady, J.A. (1974) Are PUFA harmful? British Medical Journal, 1, 115.

HoRnSTRA, G. (1974) Dietary fats and arterial thrombosis. Haemostasis, 2, 21.

Hornstra, G., Chait, A., Karvonen, M.J., Lewis, B., Turpeinen, O. \& Vergroesen, A.J. (1973) Influence of dietary fat on platelet function in men. Lancet, $\mathbf{i}, 1155$.

International Atherosclerosis Project (1968) Distribution of coronary and aortic atherosclerosis by geographic location, race and sex. Laboratory Investigation, 18, 498.

Joossens, J.V., Vuylsteek, K., Brems-Heyns, E., Carlier, J., Claes, J.H., De Backer, G., Graffer, M., Kesteloot, H., Kornitzer, M., Lequime, J., Pannier, R., Raes, A., VAN Houte, O., Vastesaeger, M. \& VerdonK, G. (1977) The patterns of food and mortality in Belgium. Lancet, $i$, 1069.

Kannel, W.B. (1976) Prospects for prevention of atherosclerosis in the young. Australian and New Zealand Journal of Medicine, 6, 410.

KANNEL, W.B. \& DAwber, T.R. (1972) Atherosclerosis as a pediatric problem. Journal of Pediatrics, 80, 544.
KEYS, A. (1970) Coronary heart disease in seven countries Circulation, 41 (Suppl. 1) I-1.

Keys, A. \& KeYs, M. (1975) How to Eat Well and Stay Welf: Doubleday \& Co. Inc., New York.

Keys, A., Anderson, J.T. \& Grande, F. (1965) Iodine value of dietary fat versus 25-P. Metabolism, 14, 747.

LeE, J.B. (1976) Prostaglandins and blood pressure controf American Journal of Medicine, 61, 681.

LOBER, P.H. (1953) Pathogenesis of coronary sclerosis American Medical Association Archives of Pathology, 5 357.

MACDONALD, I. (1973) Diet and triglyceride metabolism? Journal of Clinical Pathology, 26 (Suppl. 5), 22.

McMillaN, G.C. (1973) Development of atherosclerosis American Journal of Cardiology, 31, 542.

Miettinen, M., Turpeinen, O., Karvonen, M.J., Elosuo, R \& PaAvilainen, E. (1972) Effect of cholesterol-lowering diet on mortality from coronary heart disease and othe्s causes. Lancet, ii, 835.

Mitchell, J.R.A. \& Schwartz, C.J. (1965) Arterial Diseasę Blackwell Scientific Publications, Oxford.

MooN, H.D. (1957) Coronary arteries in fetuses, infants an丸્ juveniles. Circulation, 16, 263.

MoRris, J. (1973) Four cheers for prevention. Proceedings of the Royal Society of Medicine, 66, 5 .

National Heart and Lung Institutes (1971) Task Force on arteriosclerosis report, vol. 1 - Arteriosclerosis. DHEW Publication No. (NIH) 72-137, U.S.A. Governs ment Printing Office.

Nestel, P.J. (1974) Comment. Search, 5, 94.

Nestel, P.J., Carrol, K.F. \& Havenstein, N. (1970) Plasma triglyceride response to carbohydrates, fats \&n $\otimes^{\circ}$ calorie intake. Metabolism, 19, 1.

OsBoRn, G. (1963) Incubation Period of Coronary Thromb p. 177. Butterworths, London.

OsBorN, G. (1967) Stages in Development of Coronary Diseas Observed from 1,500 Young Subjects. Editions du centrร national de la recherche scientifique, 15 Quai Anatoles France Paris VIIe.

Pesonen, E. (1974) Coronary wall thickening in children? Atherosclerosis, 20, 173.

ROSE, G. (1975) The prevention of coronary heart disease Aberdeen Postgraduate Medical Bulletin, Jan. 14.

SCHORNAGEL, H.E. (1956) Intimal thickening in the coronar arteries in infants. Archives of Pathology, 62, 427.

Schubert, W.K. (1973) Fat nutrition and diet in childhoodo American Journal of Cardiology, 31, 581.

SinClaIR, H.M. (1968) Nutrition and atherosclerosis. In' Comparative Nutrition of Wild Animals (Ed. by Crawford? M.), p. 275.

Truswell, A.S. (1976) Diet in the pathogenesis of ischaemic heart disease. Postgraduate Medical Journal, 52, 424.

Vergroesen, A.J. (1977) Physiological effects of dietary linoleic acid. Nutrition Reviews, 35, 1.

WISSLER, R.W. (1977) Problems and progress in understand을 ing progressive atherogenesis. Cardiovascular Research. Center Bulletin, Baylor College of Medicine, 15, 69.

Wissler, R.W. \& Vesselinovitch, D. (1968) Comparativĕ pathogenic patterns in atherosclerosis. Advances in Lipid Research, 6, 181. 